\title{
Correction to: Sensitivity analysis of significant parameters affecting landfill leachate generation rate
}

\author{
Milad Ghaffariraad • Mehdi Ghanbarzadeh Lak • \\ Elham Ebrahimi Sarindizaj
}

Published online: 28 February 2022

(C) Springer Nature Switzerland AG 2022

\section{Correction to: Environ Monit Assess (2022) 194:12 https://doi.org/10.1007/s10661-021-09653-3}

The original version of this article unfortunately contained an error in the affiliation section.

The affiliation of the second author Mehdi Ghanbarzadeh Lak, was logged incorrectly. The correct author affiliation is shown below and in affiliation section.

School of Engineering, Civil Engineering Department, Urmia University, Urmia, Iran.

Publisher's Note Springer Nature remains neutral with regard to jurisdictional claims in published maps and institutional affiliations.

The original article can be found online at https://doi.org/ 10.1007/s10661-021-09653-3.

M. Ghaffariraad · M. Ghanbarzadeh Lak $(\bowtie)$

School of Engineering, Civil Engineering Department,

Urmia University, Urmia, Iran

e-mail: m.ghanbarzadehlak@urmia.ac.ir

M. Ghaffariraad

e-mail: st_m.ghaffariraad@urmia.ac.ir

E. Ebrahimi Sarindizaj

School of Civil Engineering, University of Tehran, Tehran,

Iran

e-mail: brahimielham@ut.ac.ir 